\section{JURNAL ABDIMAS

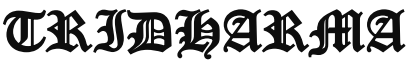

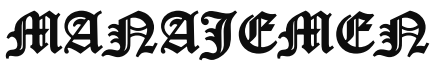

P-ISSN 2615-6849, E-ISSN 2622-3686

Jurnal ABDIMAS Vol. 2, No. 2, April 2021 Hal (26-38)

@ Prodi Manajemen Fakultas Ekonomi Universitas Pamulang

Email: abdimasjurnal.unpam@gmail.com Telp: (021) 741-2566

\title{
PERENCANAAN KARIR UNTUK PENGEMBANGAN SUMBER DAYA MANUSIA PADA MASYARAKAT DESA BELEGA GIANYAR BALI
}

\author{
Ading Sunarto, Widia Astuti, Fauziah Septiani, Rahmi Andini Syamsudin, Lisdawati \\ Dosen Prodi Manajemen Fakultas Ekonomi Universitas Pamulang \\ Email : dosen02153@unpam.ac.id,dosen02165@unpam.ac.id,dosen01771@unpam.ac.id, \\ dosen02062@unpam.ac.id, dosen02115@unpam.ac.id
}

\begin{abstract}
ABSTRAK
Tujuan dari kegiatan Pengabdian Kepada Masyarakat ini adalah untuk melaksanakan salah satu Tri Dharma Perguruan Tinggi. Selain itu, melalui kegiatan Pengabdian Kepada Masyarakat ini, diharapkan menjadi kesempatan bagi para warga desa Belega untuk berdiskusi dengan narasumber terkait dengan implementasi dan cara mengembangkan karirnya agar dapat berkembang dengan baik. Tujuan dari kegiatan Pengabdian Kepada Masyarakat ini adalah untuk melaksanakan salah satu Tri Dharma Perguruan Tinggi dan tujuan utamanya adalah untuk memberikan gambaran strategi yang dapat dilakukan dalam upaya menumbuhkan perencanaan karir para warga Desa Belega saat ini, khususnya para pengrajin bambu. Selain itu diharapkan dengan pengabdian kepada masyarakat ini keberadaan perguruan tinggi dapat memberikan kontribusi besar kepada pengembangan dan penerapan keilmuan kepada masyarakat

Metode yang kegiatan yang dilaksanakan adalah kami mendatangi langsung ke lokasi PKM yaitu di Kelurahan Belega Gianyar Bali. Hasil pengabdian kepada masyarakat yang diperoleh yakni bertambahnya dorongan motivasi warga Desa Belega untuk meningkatkan karirnya selama masa pandemic Covid-19 ini dan bertambahnya keilmuan warga Desa Belega agar mereka memiliki cara pandang yang baik tentang pentingnya meningkatkan dan membangun perencanaan karir untuk meningkatkan mutus SDM dan belajar bertanggung jawab pada masa kini sebagai bekal mereka untuk kehidupan di masa yang akan dating. Ilmu yang didapatkan pada Pengabdian Kepada Masyarakat kali ini diharapkan mampu memberikan semangat baru bagi dosen dalam upaya mengembangkan diri memberikan pengarahan, penyampaian materi dan motivasi serta berkontribusi bagi generasi muda baik di dalam lingkungan kampus, keluarga dan masyarakat secara luas.

Hasil kegiatan Pengabdian Kepada Masyarakat ini adalah bertambahnya keilmuan dan keterampilan warga Desa Belega, khususnya di bidang SDM yaitu perencanaan karirnya semakin baik dan terencana baik di masa normal maupun di masa kesulitan ekonomi seperti sekarang .

Ilmu yang didapatkan pada kegiatan Pengabdian Kepada Masyarakat ini diharapkan mampu memberikan semangat dalam menyampaikan pengetahuan dan memberikan motivasi serta berkontribusi bagi generasi muda, baik di lingkungan kampus maupun masyarakat.
\end{abstract}

\section{Kata kunci : Perencanaan Karir, Pengembangan, Sumber Daya Manusia}

\section{ABSTRACT}

The purpose of this Community Service activity is to carry out one of the Tri Dharma Perguruan Tinggi. In addition, through this Community Service activity, it is hoped that it will become an opportunity for Belega village residents to discuss with resource persons regarding 


\section{JURNAL ABDIMAS P-ISSN 2615-6849, E-ISSN 2622-3686

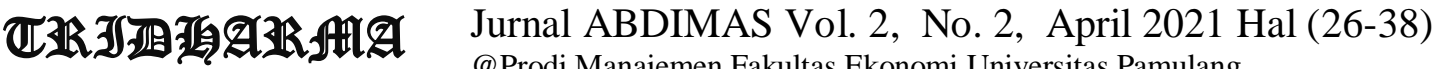

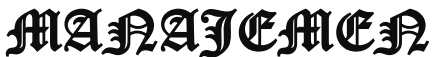

implementation and how to develop their careers so that they can develop properly. The purpose of this Community Service activity is to carry out one of the Tri Dharma of Higher Education and its main objective is to provide an overview of strategies that can be carried out in an effort to foster career planning for the residents of Belega Village today, especially bamboo craftsmen. In addition, it is hoped that with this community service, the existence of universities can make a major contribution to the development and application of science to the community

The method by which the activities are carried out is that we go directly to the PKM location, namely in the Belega Gianyar Village, Bali. The results of community service obtained are the increased motivation of Belega Village residents to improve their careers during the Covid-19 pandemic and the increased knowledge of Belega Village residents so that they have a good perspective on the importance of improving and building career planning to improve HR quality and learn to be responsible. answer in the present as their provision for life in the future. The knowledge gained in Community Service this time is expected to be able to provide new enthusiasm for lecturers in an effort to develop themselves in providing direction, delivery of material and motivation as well as contributing to the younger generation both in the campus environment, family and society at large.

The result of this Community Service activity is the increase in knowledge and skills of Belega Village residents, especially in the HR sector, namely that their career planning is getting better and better planned both in normal times and in times of economic difficulties like now.

The knowledge gained in this Community Service activity is expected to be able to provide enthusiasm in conveying knowledge and provide motivation and contribute to the younger generation, both in the campus and in the community.

\section{Keywords: Career Planning, Development, Human Resources}

\section{PENDAHULUAN}

Belega adalah desa yang berada di kecamatan blahbatu, kabupaten giayar provinsi bali, desa belega merupakan sentra kerajinan barang dari bamboo, seperti kursi, ranjang, meja hias, lemari dll. Penduduk desa Belega sampai dengan tahun 2016 berjumlah 4.606 jiwa terdiri dari 2.287 lakilaki dan 2.319 perempuan.

Belega memang terkenal dengan kerajinan bambunya. Dengan mengandalkan krajinan bambu masyarakat setempat mendapatkan berkah untuk memenuhi kebutuhan hidupnya. Bahkan, keberadaan kerajinan bambu ini telah mampu mengangkat nama Desa Belega ke kancah pasar nasional dan internasional. Berbagai produk kerajinan yang dihasilkan oleh masyarakat dijual ke luar wilayah Bali, bahkan ke luar negeri. Perkembangan yang cukup pesat ini merupakan hal yang tidak diduga. Pasalnya, di Desa Pakraman Belega yang luasnya sekitar $55 \mathrm{~km} 2$ di mana sekitar
40 persennya merupakan lahan pertanian, tidak ditemukan pohon bambu. Dengan mengandalkan bambu pasokan dari luar daerah hasil kerajinan Belega mampu bertahan sebagai satu-satunya perolehan ekonomi masyarakat Belega.

Permasalahan kematangan karir merupakan permasalahan harus dipersiapkan dengan sebaik-baiknya, seperti dalam hal merencanakan dan mengambil suatu keputusan karir.

Berikut pemaparan mengenai permasalahan karir :

1. Kurangnya pemahaman tentang dirinya, terutama potensi dasar (bakat, minat, sikap, kecakapan, dan cita-cita) yang terkait dengan dunia kerja yang akan dimasukinya kelak. Keberhasilan atau kenyamanan dalam suatu karier amat dipengaruhi oleh kemampuan individu memahami dan menilai potensi dasar yang dimilikinya. Oleh karena itu, maka setiap siswa perlu dibantu untuk memahami potensi dasar 


\section{JURNAL ABDIMAS

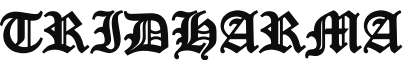

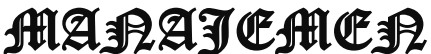

dirinya, sehingga menentukan pilihan atau mengambil keputusan yang sesuai dengan dunia kerja pilihannya itu.

2. Kurangnya kesadaran nilai-nilai yang ada pada diri dan masyarakatnya, sehingga menumbuhkan sikap negatif terhadap dunia kerja. Sikap negatif berarti bahwa individu tidak mau bekerja dalam bidang pekerjaan apa pun dan tidak sesuai dengan norma agama yang dianutnya

3. 3. Kurangnya pengetahuan mengenai lingkungan pekerjaan yang berhubungan dengan potensi serta pemahaman jenis-jenis pelatihan yang diperlukan untuk mengembangkan karier dalam bidang pekerjaan tertentu. Melalui pengetahuan dan pemahaman tersebut individu terdorong untuk membentuk identitas karier dengan cara mengenali ciri-ciri pekerjaan, persyaratan yang dituntut, lingkungan pekerjaan, prospek kerja, dan kesejahteraan kerja

4. Tidak dapat menemukan dan mengatasi hambatan-hambatan yang disebabkan oleh faktor diri dan lingkungannya.

5. Tidak mampu merencanakan masa depan, yaitu tidak mampu merancang kehidupan rasional untuk memperoleh peran-peran yang sesuai dengan minat, kemampuan, dan kondisi kehidupan sosial-ekonomi

6. Tidak mampu membentuk pola-pola karier yang berhubungan dengan kecenderungan arah karier, Misalnya, apabila seorang siswa bercita-cita menjadi pemandu wisata, dia senantiasa harus mengarahkan dirinya kepada kegiatan-kegiatan yang relevan dengan karier kepariwisataan.

7. Kurang mempunyai motivasi untuk mencari informasi tentang dunia kerja

8. Belum memiliki pilihan perguruan tinggi tertentu, jika setelah tamat tidak masuk dunia kerja

9. Ragu-ragu apakah sekolah atau jurusan yang dipilih sudah tepat atau belum

10. Takut akan mengalami kegagalan dalam memilih pekerjaan

11. Keadaan tubuh yang kurang cocok dengan pekerjaan yang diinginkan
Perlu diberikan pelatihan untuk penyusunan rencana karir agar dapat memetakan langkah yang harus mereka ambil. Rencana karir juga dapat membuka wawasan mereka mengenal yang dapat di lakukan kedepannya.

Desa Belega di Gianyar nyaris identik dengan kerajinan bambu. Dari mulai furniture, bed, kursi santai hingga pernakpernik lainnya dihasilkan oleh perajin di desa ini. Sempat mengalami kejayaan, sejak peristiwa bom Bali 2002 sentra kerajinan ini seperti ditinggalkan pembeli. Salah satu pengusaha yang masih bertahan, Made Sujana Yasa, yang mewarisi kerajinan ini dari kakeknya sekitar sejak Tahun 1960-an, menyebut masih bertahan, walau pemintanya sedikit. "Kami memilih bertahan di usaha ini. Usaha ini warisan dari kakek dan kami masih memiliki pelanggan dari Perancis," ujarnya, pekan lalu. Saat masa jayanya, dirinya memperkerjakan tenaga sampai 25 orang, kini ia hanya mengajak 7 tenaga, itupun selang seling, tergantung adanya pesanan.

Untuk furniture satu set kursi-meja bamboo, harganya masih di RP 1,2 juta. Ini juga tergantung motif dan tambahannya seperti busa. Walau dengan harga semurah itu, furniture ini jarang dilirik baik warga lokal dan wisatawan. Dari bambu, menurutnya bisa berinovasi dengan membuat apa saja, asal kreatif. Sedangkan saat ini, trend masyarakat membuat gazebo (bale bengong) dari bamboo dengan ukuran sekitar 3 X 3 meter. Harga gazebo ini paling rendah Rp 15 juta, dengan bangunan sederhana atap alang-alang. Untuk bamboo biasanya didatangkan dari Tabanan, Bangli atau dari Jawa. Sujana Yasa menyebutkan, Desa Belega sebagai sentra kerajinan bambu ingin dibangkitkan lagi. Belega sudah memiliki branding sebagai sentra kerajinan bambu dan memiliki SDM yang memadai. "Sehingga kami bersama pengusaha lain ingin membangkitkan kembali dengan membuat Wisata Kampung Bambu," terangnya.

\section{RUMUSAN MASALAH}

Ketut Trisna Jaya mengakui kalau kondisi kerajinan bambu di wilayahnya 


\section{JURNAL ABDIMAS \\ P-ISSN 2615-6849, E-ISSN 2622-3686

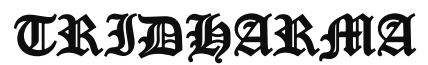 \\ Jurnal ABDIMAS Vol. 2, No. 2, April 2021 Hal (26-38) \\ @ Prodi Manajemen Fakultas Ekonomi Universitas Pamulang

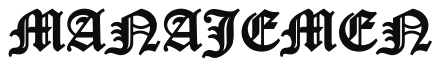 \\ Email: abdimasjurnal.unpam@gmail.com Telp: (021) 741-2566}

terpuruk. "Sudah hampir 20 tahun belakangan ini terpuruk, saat ini kami berusaha membangkitkannya," terang Trisnu Jaya. Sebelumnya di masa jaya, sebanyak 350 warganya sebagai perajin dan kini hanya 35 usaha saja yang masih bertahan. "Selebihnya sebagai buruh bangunan, nyakap pertanian atau bekerja di luar daerah menekuni kerajinan bamboo," terangnya. Salah satu gagasan untuk mengembalikan Desa Belega, Kecamatan Blahbatuh sebagai sentra kerajinan bambu dengan membuat Desa Wisata Kampung Bambu. Rencana ini disebutnya sedang digodok dan Banjar Belega Kangin akan dijadikan pilot projek.

"Ini dimulai dari wajah banjar yang mencerminkan bambu, warung menggunakan bahan bambu termasuk nanti ada semacam mosaik tanaman bambu," terangnya lagi. Dirinya berharap dengan membuat desa wisata kampung bambu, kejayaan kerajinan bambu di wilayahnya bisa bangkit kembali.

Adapun permasalahan lain :

\section{Rendahnya tingkat pendidikan}

Sarana pendidikan masyarakat di desa cenderung rendah. Masyarakat di desa umumnya hanya berpendidikan SD, SMP dan SMA. Hal ini disebabkan karena masyarakat belum mengetahui seberapa besar pentingnya pendidikan untuk dirinya. Apabila setelah menyelesaikan pendidikan hingga SMA atau lebih buruk hanya sampai SD saja orang tua akan menikahkan anakanaknya sehingga masa depan pendidikan generasi penerus bangsa menjadi terputus dan hal ini menyebabkan mereka hanya bergelut pada lingkar kemiskinan karena minimnya pendidikan. Rendahnya pendidikan ini juga menjadi menjadi akar permasalahan bahwa kurangnya inisiatif masyarakat dalam menghadapi masalahmasalah dalam kehidupan mereka. Mereka hanya memikirkan bagaimana caranya agar tetap mempertahankan hidup tanpa memikirkan bagaimana nasib generasi penerus bangsa di masa yang akan mendatang. Karena minimnya pendidikan masyarakat hal ini menyebabkan dari seluruh penduduk desa hampir 95\% penduduk bermata pencaharian sebagai petani. Selain itu masalah rendahnya pendidikan juga menjadikan kendala dalam penerapan inovasi yang dilakukan oleh penyuluhan.

\section{Minimnya sarana dan prasarana di pedesaan}

Salah satu penyebab daerah pedesaan masih terisolasi atau tertinggal adalah masih minimnya prasarana dan sarana transportasi yang membuka akses daerah pedesaan dengan daerah lainnya. Kondisi prasarana dan sarana transportasi yang minim berkontribusi terhadap keterbelakangan ekonomi daerah pedesaan. Secara umum, masyarakat daerah pedesaan menghasilkan jenis produk yang relatif sama, sehingga transaksi jual beli barang atau produk antar sesama penduduk di suatu desa relatif kecil. Dalam kondisi prasarana dan sarana transportasi yang minim, produk yang dihasilkan masyarakat daerah pedesaan sulit untuk diangkut dan dipasarkan ke daerah lain. Jika dalam kondisi seperti itu, masyarakat daerah pedesaan menghasilkan produk pertanian dan non pertanian dalam skala besar, maka produk tersebut tidak dapat diangkut dan dipasarkan ke luar desa dan akan menumpuk di desa. Penumpukan dalam waktu yang lama akan menimbulkan kerusakan dan kerugian. Kondisi seperti ini sangat tidak menguntungkan bagi warga masyarakat di daerah pedesaan. Sebaliknya, hal tersebut akan mendorong sebagian warga masyarakat di daerah pedesaan untuk merantau atau berpindah ke daerah lain terutama daerah perkotaan yang dianggap lebih menawarkan masa depan yang lebih baik.

\section{Terbatasnya lapangan pekerjaan di pedesaan \\ Indonesia sebagai negara agraris} sampai saat ini dapat dilihat dari besarnya jumlah penduduk yang masih mengandalkan penghasilannya serta menggantungkan harapan hidupnya pada sektor pertanian. Dominasi sektor pertanian sebagai matapencaharian penduduk dapat terlihat nyata di daerah pedesaan. Sampai saat ini lapangan kerja yang tersedia di daerah pedesaan masih didominasi oleh sektor usaha bidang pertanian. Kegiatan usaha 


\section{JURNAL ABDIMAS

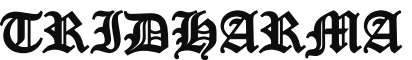 AtA}

ekonomi produktif di daerah pedesaan masih sangat terbatas ragam dan jumlahnya, yang cenderung terpaku pada bidang pertanian (agribisnis). Aktivitas usaha dan matapencaharian utama masyarakat di daerah pedesaan adalah usaha pengelolaan/ pemanfaatan sumber daya alam yang secara langsung atau tidak langsung ada kaitannya dengan pertanian. Bukan berarti bahwa lapangan kerja di luar sektor pertanian tidak ada, akan tetapi masih sangat terbatas. Peluang usaha di sektor non-pertanian belum mendapat sentuhan yang memadai dan belum berkembang dengan baik. Kondisi ini mendorong sebagian penduduk di daerah pedesaan untuk mencari usaha lain di luar desanya, sehingga mendorong mereka untuk berhijrah/migrasi dari daerah pedesaan menuju daerah lain terutama daerah perkotaan. Daerah perkotaan dianggap memiliki lebih banyak pilihan dan peluang untuk bekerja dan berusaha.

\section{TUJUAN KEGIATAN}

Kegiatan pelatihan ini diharapkan mampu memberikan dampak jangka panjang bagi kehidupan warha masyarakat Desa Belega, sebagai berikut :

a. Memberikan pengetahuan kepada warga Desa Belega yang masih berusia produktif mengenai pentingnya perencanaan karir dalam mengatur dan mengelola kompetensinya untuk mencapai tujuan Sumber Daya Manusia yang efektif

b. Memberikan pengetahuan kepada warga Desa Belega yang masih berusia produktif terutama mengenai cara membuat perencanaan karir untuk pengembangan dirinya dan keluarganya.

\section{TINJAUAN PUSTAKA \\ Perencanaan Karir}

Di lingkup sekolah, aktivitas yang dulu disebut sebagai layanan informasi (yaitu menyediakan informasi tentang pekerjaan dan pendidikan) sejak tahun 1970-an, konsep layanan dasarnya meluas dan sebuah label baru (yang lebih tepat) diberikan: bimbingan karir. Gibson dan Mitchell mendefinisikan Karir (career) sebagai jumlah total pengalaman kerja seseorang di dalam kategori pekerjaan umum seperti mengajar, akutansi, pengobatan, atau penjualan. Pekerjaan (occupation) adalah sebuah aktivitas spesifik dari pekerjaan atau karya.

Menurut Gibson dan Mitchell, pengembangan karir (career development) adalah asas dari pengembangan total individu yang menitih beratkan pembelajaran, persiapan, cara memasuki dan kemajuan. Pendidikan karir (career education) adalah pengalaman pendidikan terencana yang memfasilitasi pengembangan karir seseorang dan mempersiapkannya masuk ke dunia kerja. Sedangkan Bimbingan Karir (career guidance) diartikan sebagai aktivitas yang dilakukan konselor di berbagai lingkup dengan tujuan menstilmulsi dan memfasilitasi perkembangan karier seseorang di sepanjang usia bekerjanya. Aktivitas ini meliputi bantuan dalam perencanaan pengambilan keputusan dan penyesuaian diri.

\section{Teori - Teori Pengembangan Karir Dan Pengambilan Keputusan}

Menurut Ginzberg perkembangan dalam proses pilihan karir mencakup tiga tahap yang utama, yaitu fantasi, tentatif, dan realistik. Dua masa daripadanya, yaitu tentatif dan realistik, masing-masing dibagi atas beberapa tahap. Masa tentatif mencakup usia lebih kurang 11 sampai 18 tahun (masa anak bersekolah di SMP dan SMA) dan meliputi empat tahap, yaitu minat, kapasitas, nilai dan transisi. Masa realistik adalah masa usia anak mengikuti kuliah atau mulai bekerja. Masa ini pun bertahap, yaitu eksplorasi, kristalisasi, dan spesifikasi. Teori Ginzberg mempunyai tiga unsur, yaitu proses (bahwa pilihan suatu pekerjaan adalah suatu proses), irreversibilitas (bahwa pilihan pekerjaan tidak bisa diubah atau dibalik), dan kompromi (bahwa pilihan pekerjaan itu kompromi antara faktor-faktor yang main, yaitu minat kemampuan dan nilai). Teori ini kemudian mendapat revisi pada tahun 1970. Proses yang semula berakhir pada awal masa dewasa atau akhir masa remaja, kemudian dirumuskan bahwa 


\section{JURNAL ABDIMAS

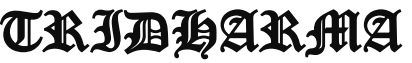

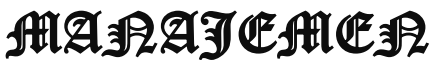

P-ISSN 2615-6849, E-ISSN 2622-3686

Jurnal ABDIMAS Vol. 2, No. 2, April 2021 Hal (26-38)

@ Prodi Manajemen Fakultas Ekonomi Universitas Pamulang

Email: abdimasjurnal.unpam@gmail.com Telp: (021) 741-2566 hal ni tidak demikian halnya tetapi berlangsung terus. Mengenai irreversibilitas, adanya pembatasan pilihan tidak mesti berarti bahwa pilihan tersebut bersifat menentukan. Apa yang terjadi sebelum orang berumur 20 tahun mempengaruhi karirnya. Terjadinya kesempatan bisa saja menyebabkan orang berubah dalam pekerjaannya.

Para pakar memberikan pengertian keputusan sesuai dengan sudut pandang dan latar belakang pemikirannya. Menurut James A.F. Stoner, keputusan adalah pemilihan di antara berbagai alternatif. Definisi ini mengandung tiga pengertian, yaitu: (1) ada pilihan atas dasar logika atau pertimbangan; (2) ada beberapa alternatif yang harus dipilih salah satu yang terbaik; dan (3) ada tujuan yang ingin dicapai dan keputusan itu makin mendekatkan pada tujuan tersebut. Pengertian keputusan yang lain dikemukakan oleh Prajudi Atmosudirjo bahwa keputusan adalah suatu pengakhiran daripada proses pemikiran tentang suatu masalah dengan menjatuhkan pilihan pada suatu alternatif.

Dari pengertian keputusan tersebut dapat diperoleh pemahaman bahwa keputusan merupakan suatu pemecahan masalah sebagai suatu hukum situasi yang dilakukan melalui pemilihan satu alternatif dari beberapa alternatif.

Sementara itu, George R. Terry menyebutkan 5 dasar (basis) dalam pengambilan keputusan, yaitu:

\section{Intuisi.}

Pengambilan keputusan berdasarkan intuisi adalah pengambilan keputusan yang berdasarkan perasaan yang sifatnya subyektif. Dalam pengambilan keputusan berdasarkan intusi ini, meski waktu yang digunakan untuk mengambil keputusan relatif pendek, tetapi keputusan yang dihasilkan seringkali relatif kurang baik karena seringkali mengabaikan dasar-dasar pertimbangan lainnya.

\section{Pengalaman.}

Pengambilan keputusan berdasarkan pengalaman memiliki manfaat bagi pengetahuan praktis, karena dengan pengalaman yang dimiliki seseorang, maka dapat memperkirakan keadaan sesuatu, dapat memperhitungkan untung-ruginya dan baik-buruknya keputusan yang akan dihasilkan.

\section{Wewenang.}

Pengambilan keputusan berdasarkan wewenang biasanya dilakukan oleh pimpinan terhadap bawahannya, atau oleh orang yang lebih tinggi kedudukannya kepada orang yang lebih rendah kedudukannya. Hasil keputusannya dapat bertahan dalam jangka waktu yang cukup lama dan memiliki otentisitas (otentik), tetapi dapat menimbulkan sifat rutinitas, mengasosiasikan dengan praktek diktatorial dan sering melewati permasalahan yang seharusnya dipecahkan sehingga dapat menimbulkan kekaburan

\section{Fakta.}

Pengambilan keputusan berdasarkan data dan fakta empiris dapat memberikan keputusan yang sehat, solid dan baik. Dengan fakta, tingkat kepercayaan terhadap pengambil keputusan dapat lebih tinggi, sehingga orang dapat menerima keputusan yang dibuat itu dengan rela dan lapang dada.

\section{Rasional.}

Pada pengambilan keputusan yang berdasarkan rasio, keputusan yang dihasilkan bersifat objektif, logis, lebih transparan dan konsisten untuk memaksimumkan hasil atau nilai dalam batas kendala tertentu, sehingga dapat dikatakan mendekati kebenaran atau sesuai dengan apa yang diinginkan. Pengambilan keputusan secara rasional ini berlaku sepenuhnya dalam keadaan yang ideal. Pada pengambilan keputusan secara rasional terdapat beberapa hal sebagai berikut:

a. Kejelasan masalah: tidak ada keraguan dan keaburan masalah.

b. Orientasi tujuan: kesatuan pengertian tujuan yang ingin dicapai.

c. Pengetahuan alternatif: seluruh alternatif diketahui jenisnya dan konsekuensinya.

d. Preferensi yang jelas: alternatif bisa diurutkan sesuai kriteria. 


\section{JURNAL ABDIMAS

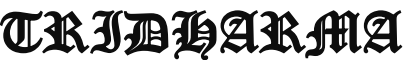 AtA}

e. Hasil maksimal: pemilihan alternatif terbaik berdasarkan atas hasil ekonomis yang maksimal.

Tjuan Dan Fungsi Bimbingan Karir Dan Konseling :

Secara umum tujuan bimbingan karir dan konseling sebagai berikut:

1. Memiliki pemahaman diri (kemampuan, minat, dan kepribadian) yang terkait dengan pekerjaan. Memiliki pengetahuan mengenai dunia kerja dan informasi karir yang menunnjang kematangan kompetensi kerja.

2. Memiliki sikap positif terhadap dunia kerja. Dalam arti mau bekerja dalam bidang pekerjaan apa pun, tanpa merasa rendah diri, asal bermakna bagi dirinya dan sesuai dengan norma agama. Memahami relevansi kompetensi belajar (kemampuan menguasai pelajaran) dengan persyaratan keahlian atau keterampilan bidang pekerjaan yang menjadi cita-cita karirnya masa depan.

3. Memiliki kemampuan untuk membentuk identitas karir dengan cara mengenali ciri-ciri pekerjaan, kemampuan (persyaratan) yang dituntut, lingkungan sosiopsikologis pekerjaan, prospek kerja, dan kesejahteraan kerja.

4. Memiliki kemampuan merencanakan masa depan, yaitu merancang kehidupan secara rasional untuk memperoleh peran-peran yang sesuai dengan minat, kemampuan, dan kondisi kehidupan sosial ekonomi.

5. Mengenal keterampilan, minat, dan bakat. Keberhasilan atau kenyamanan dalam suatu karir amat dipengaruhi oleh minat dan bakat yang dimiliki. Oleh karena itu, setiap orang perlu memahami kemampuan dan minatnya.

6. Dalam bidang pekerjaan apa dia mampu dan apakah dia berminat terhadap pekerjaan tersebut.

7. Memiliki kemampuan atau kematangan untuk mengambil keputusan karier.

8. Memiliki kemampuan untuk menciptakan suasana hubungan industrial yang harmonis, dinamis, berkeadilan, dan bermartabat.

\section{Cara Membuat Perencanaan Karir}

Berikut 10 langkah yang dapat membantu Anda membuat dan meraih perencanaan karier Anda.

\section{Tentukan Visi Anda}

Awali perencanaan karier dengan mengetahui visi Anda. Visi, menurut Cambridge Dictionary, adalah pandangan masa depan (view of the future). Visi Anda adalah tentang diri Anda di masa mendatang, 5 sampai 10 tahun ke depan. Jika Anda termasuk karyawan yang tidak mengetahui secara pasti apa visi Anda, tanyakan kepada diri apa yang Anda inginkan di masa mendatang. Bayangkan akan menjadi apa diri Anda beberapa tahun ke depan. Jika masih susah membayangkan sampai 5 tahun atau 10 tahun, mulailah dengan visi 2 sampai 3 tahun. Menentukan visi untuk beberapa tahun mendatang tidak seperti memilih pakaian yang akan Anda gunakan hari ini. Setelah menentukan sebuah visi, Anda perlu mengujinya, apakah hal itu memang benar-benar yang Anda inginkan di masa mendatang.

\section{Kenali Diri: Kekuatan dan Kelemahan}

Setelah menentukan visi Anda, langkah perencanaan karier berikutnya adalah mengenal diri Anda dengan melihat kekuatan dan kelemahan. Hal ini memang agak sulit karena terkadang kekuatan lebih sering terlihat daripada kelemahan. Untuk mendapatkan sebuah penilaian yang objektif tentang kekuatan dan kelemahan diri Anda, mintalah pendapat dari beberapa teman dekat. Catatlah hal-hal yang mereka ungkap mengenai kekuatan dan kelemahan diri Anda. Jangan langsung menyimpulkan dari pendapat teman-teman dekat Anda. Gunakan pendapat dari teman-teman sebagai bahan pertimbangan. Andalah yang harus mengambil peran lebih banyak untuk mengenal kekuatan dan kelemahan karena Anda adalah orang yang paling mengerti diri Anda.

\section{Review Pencapaian Masa Lalu}




\section{JURNAL ABDIMAS

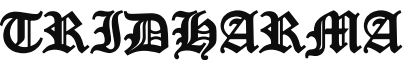 AtA}

Tantangan terbesar seorang karyawan adalah mencatat penghargaan atau prestasi yang ia peroleh saat bekerja. Apalagi sudah berada di posisi aman, misalnya di bagian manajemen, kebanyakan karyawan tidak menyimpan catatan yang baik dari prestasi kerja yang nantinya akan sangat bermanfaat saat mencari pekerjaan baru. Membuat catatan prestasi kerja Anda dan menyimpan catatan tersebut dengan baik tidak hanya berguna untuk membuat resume atau $\mathrm{CV}$ yang menarik, tetapi juga berguna untuk perencanaan karier Anda. Meninjau prestasi kerja atau pencapaian masa lalu akan memberikan gambaran tentang masa lalu Anda dan masa sekarang yang sangat membantu perencanaan masa depan. Hasil review pencapaian prestasi kerja akan membuat Anda lebih mengenal diri dan mengetahui hal-hal yang membuat Anda bangga dan bahagia.

\section{Catat Keterampilan yang Anda Kuasai}

Langkah selanjutnya adalah mencatat keterampilan yang Anda kuasai agar dapat merencanakan masa depan dengan lebih baik. Daripada mencatat jenis pekerjaan yang Anda lakukan, akan lebih baik jika Anda merangkum keterampilanketerampilan yang Anda kuasai. Misalnya, jenis pekerjaan reporter biasanya memiliki keterampilan melakukan observasi, menginterview, menginvestigasi, menulis, mengedit, dan lain sebagainya. Dengan mengetahui keterampilan yang dikuasai, si reporter tidak perlu terus-menerus melamar pekerjaan sebagai reporter. Ia dapat menyesuaikan jenis pekerjaan yang berhubungan dengan keterampilan yang ia kuasai. Dengan mengetahui keterampilan yang Anda kuasai, perencanaan karier akan lebih mudah dilakukan karena Anda tidak terbatas dengan satu jenis pekerjaan saja.

\section{Ketahui Passion Anda}

Berbeda dengan hobi, passion adalah sesuatu yang bukan saja senang Anda lakukan tetapi Anda akan melakukannya walaupun harus mengorbankan uang, waktu dan tenaga Anda. Kepuasan dan rasa bahagia yang Anda dapatkah setelah melakukannya adalah nilai yang tak bisa dibayar dengan apapun juga. Itulah passion. Kenali diri Anda lebih dalam dengan mengetahui passion Anda. Apabila Anda adalah seorang karyawan di perusahaan pertambangan dan Anda sangat tertarik di bilang teknologi terutama komputer, ada baiknya Anda mengembangkan minat Anda di bidang itu sepulang kerja. Bisa jadi Anda akan menemukan passion di bidang teknologi komputer. Sebenarnya, passion dan karier bisa menjadi hal yang bertautan atau malah bertentangan. Hal terbaik yang dapat Anda lakukan adalah mengarahkan passion menjadi karier Anda, di masa mendatang. Jika masih belum bisa, Anda harus bersabar dan terus melakukan perencanaan karier serta pengembangan passion.

\section{Analisis Tren dan Peluang Pekerjaan}

Langkah keenam adalah menganalisis tren dan peluang kerja yang ada di Indonesia. Kalaupun Anda memiliki keterampilan yang sangat baik dan $\mathrm{CV}$ yang menggiurkan dan menarik, tetap saja Anda harus mencari-cari lowongan kerja dan peluang kerja (baca: 10 perusahaan idaman di Indonesia) yang sesuai dengan keterampilan dan prestasi kerja Anda sebelumnya. Memiliki informasi tentang tren karier dan peluang pekerjaan sangat penting untuk kesuksesan perencanaan karierjangka panjang. Sebuah karier bisa saja berkembang saat ini dan menyusut bulan depan atau tahun depannya. Menganalisis tren dan peluang kerja sangat penting untuk melihat di mana pertumbuhan pekerjaan yang diharapkan, terutama dalam ladang karieryang paling Anda minati. Keuntungan lain yang Anda dapatkan dari meneliti tren dan peluang pekerjaan untuk dapat menyesuaikan dan memperkuat posisi Anda dan mengetahui hal-hal yang Anda butuhkan untuk perencanaan karier ke depan.

\section{Rencanakan Karier Anda yang SMART}

Langkah selanjutnya adalah poin utama dari topik ini yaitu perencanaan karier Anda. Jika Anda memutuskan perencanaan karier jangka pendek, buatlah sampai 2 atau 3 tahun ke depan. Setelah menentukan apa yang akan Anda lakukan beberapa tahun ke 


\section{JURNAL ABDIMAS

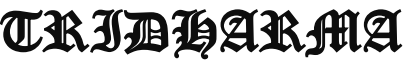

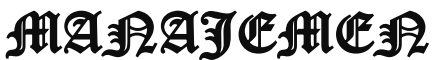

depan, mulailah menyusun perencanaan setiap tahunnya, setiap 6 bulan dan bahkan goal setiap bulannya. Gunakan langkah pertama sampai keenam sebelumnya untuk membantu Anda menentukan pencapaian setiap bulan atau setiap 6 bulan untuk meraih karier yang Anda idamkan.

Banyak contoh perencanaan karier yang ditampilkan di mesin pencari Google. Dalam perencanaan karier, Anda harus ingat kriteria SMART yaitu Specific, Measureabl e, Achievable, Realistic, dan Time-bound, yang mana setiap tujuan yang ingin dicapai haruslah spesifik, dapat dicapat, relalistis dan memiliki tenggat waktu.

\section{Bertindak Sesuai Rencana}

Sebuah perencanaan yang matang dan detail tidak akan berarti apa-apa tanpa adanya eksekusi. Jadi hal selanjutnya yang harus Anda lakukan setelah membuat perencanaan karier yang SMART adalah bertindak sesuai rencana. Perencanaan yang detail sampai hitungan mingguan dan bahkan harian akan memudahkan Anda mengukur sejauh mana Andatelah melangkah dan berapa lama Anda akan sampai di tujuan.

\section{Tingkatkan Keterampilan dan Pendidikan Anda}

Hal yang tak kalah penting dalam perencanaan karier adalah terus belajar dan mengembangkan keterampilan dan pendidikan Anda. Jangan lihat langkah ini hanya sebagai sarana untuk meningkatkan kinerja di perusahaan tempat Anda bekerja saat ini, tetapi lihatlah hal-hal yang Anda dapatkan yaitu memperluas wawasan, koneksi dan mengembangkan keterampilan untuk masa depan Anda. Dalam kegiatan pengembangan keterampilan dan pendidikan, Anda akan bertemu orang-orang baru yang akan membantu meningkatkan dan memajukan karier Anda. Luangkan waktu untuk mencari jenis pendidikan, pelatihan, kuliah secara online dan offline yang dapat membantu mencapai karier yang Anda idamkan.

\section{Evaluasi Perencanaan Karier Anda}

Sama seperti bagian tubuh yang diperiksa secara rutin oleh ahlinya, perencanaan karier Anda pun wajib dievaluasi secara rutin misalnya 6 bulan atau setahun sekali. Kegiatan evaluasi ini bertujuan untuk mengontrol dan memperbaiki hal-hal yang telah dilakukan namun di luar jalur perencanaan karier. Selain itu, dengan melakukan evaluasi terhadap perencanaan karier, Anda juga dapat melihat metode yang efektif digunakan untuk mencapai tujuan.

\section{METODE PELAKSANAAN}

Metode kegiatan pengabdian kepada masyarakat ini dibagi menjadi beberapa tahap. Tahap pertama adalah identifikasi masalah yang dilakukan sebagai langkah awal untuk merumuskan apa saja yang akan dijadikan bahan untuk perancangan sistem dan materi pelatihan dalam kegiatan pengabdian kepada masyarakat ini.

Tahap berikutnya yaitu melakukan survei lapangan ke Kelurahan Desa Belega Gianyar Bali. Tim pelaksana kemudian melakukan proses wawancara dan diskusi dengan pihak Lurah Belega dan Masyarakat Desa Belega untuk mengidentifikasi permasalahan yang ada dalam lingkungan warganya untuk kemudian merumuskan solusi dan penyelesaiannya serta menentukan keluaran yang diharapkan oleh mitra. Pada tahap ini anggota tim pelaksana berdiskusi menentukan tema dan materi yang akan disampaikan, bahan dan alat yang diperlukan, serta persiapan teknis lainnya yang dibutuhkan untuk kelancaran pelaksanaan kegiatan pengabdian kepada masyarakat ini. Permasalahan yang ditemukan pada warga Desa Belega adalah belum mengetahui pentingnya perencanaan karir dalam meningkatkan Sumber Daya Manusia.

Tahap berikutnya adalah pelaksanaan kegiatan. Kegiatan ini dilaksanakan di tempat mitra, yaitu di Kantor Kelurahan Belega Gianyar Bali, pada hari Senin 8 Maret 2021 sampai dengan hari Rabu 10 Maret 2021 mulai pukul 10.00 sampai pukul 14.00 WIB. Kegiatan ini dilakukan dengan memberikan penyuluhan kepada warga Desa Belega yang tergolong masih berusia produktif tentang pentingnya 


\section{JURNAL ABDIMAS

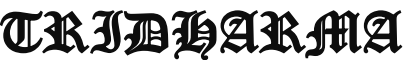 AtA}

perencanaan karir, mengapa kita harus membuat perencanaan karir, manfaat membuat perencanaan karir dan cara membuat perencanaan karir. Penyampaian materi menggunakan metode presentasi dengan media Microsoft Power Point. Peserta yang mengikuti kegiatan ini sebanyak 30 orang. Peserta adalah warga desa pilihan dari berbagai elemen sosial.

Pihak mitra, yaitu Lurah Desa Belega menyediakan ruang kegiatan yang memadai dan nyaman. Hal yang perlu diperhatikan yaitu cara mengatur (formasi) tempat duduk. Karena masih berada di masa pandemi, maka peserta dibatasi hanya 30 orang dan pengaturan tempat duduk serta pelaksanaan kegiatannya disesuaikan dengan protokol kesehatan (duduk diatur agar berjarak, tetap menggunakan masker, mencuci tangan setelah kegiatan, dan protokol kesehatan lainnya).

Untuk menunjang la kegiatan
pelaksanaan alat bant
diperlukanbeberapa alat
pembelajaran tertentu, yaitu :
1) LCD (Liquid Crystal Display)
2) Laptop
3) Spidol
4) White board
5) Buku catatan

Tahap terakhir dalam kegiatan pengabdian kepada masyarakat ini yaitu tindak lanjut dari pelaksanaan kegiatan ini. Pada tahap ini dilakukan diskusi atau tanya jawab tentang permasalahan seputar perencanaan karir yang dihadapi warga desa Belega, membahas materi perencanaan karir serta tips membuat rencana karir yang baik, kemudian dilakukan simulasi perencanaan karir kepada warga Desa Belega.

Kegiatan pengabdian kepada masyarakat ini bertujuan untuk membuat warga Desa Belega menyadari pentingnya perencanaan karir dalam kehidupannya dan mulai membuat perencanaan karir secara pribadi. Pengetahuan ini diharapkan dapat ditularkan pula kepada anggota keluarga mereka masing-masing. Target lain yang ingin dicapai dalam kegiatan pengabdian kepada masyarakat ini adalah timbulnya motivasi dalam diri tim pelaksana kegiatan untuk membuat sebuah tulisan ilmiah terkait Perencanaan Karir Untuk Mengembangkan $S D M$ dan mempublikasikan hasil tulisan tersebut ke dalam jurnal Pengabdian Kepada Masyarakat.

\section{HASIL DAN PEMBAHASAN Hasil Kegiatan}

Berdasarkan wawancara, tanya jawab dan pengamatan langsung selama kegiatan berlangsung, kegiatan pengabdian pada masyarakat ini memberikan hasil sebagai berikut :

a. Meningkatnya pengetahuan warga

Desa Belega mengenai perencanaan karir yang harus dimiliki sejak muda agar bisa membuat rencana karir terbaik untuk masa depannya.

b. Meningkatnya motivasi warga Desa Belega untuk membuat perencanaan karir dan menerapkannya dalam keseharian mereka.

\section{Faktor Pendukung dan Faktor Penghambat}

Beberapa faktor yang mendukung terlaksananya kegiatan pengabdian pada masyarakat ini adalah besarnya minat dan antusiasme peserta selama kegiatan, sehingga kegiatan berlangsung dengan lancar dan efektif. Sedangkan faktor penghambatnya adalah keterbatasan waktu pelatihan dan fasilitas peralatan yang masih minim.

\section{Pembahasan}

Untuk melaksanakan kegiatan PKM ini digunakan beberapa metode penyuluhan yaitu sebagai berikut :

a. Metode Ceramah $\rightarrow$ Metode yang digunakan dalam penyuluhan ini yaitu penyuluhan dengan memberikan ceramah atau presentasi dengan tema "Perencanaan Karir Untuk Pengembangan Sumber Daya Manusia" b. Metode Diskusi Dan Tanya Jawab $\rightarrow$ Setelah sesi pemberian materi selesai, maka dilanjutkan dengan sesi 

JURNAL ABDIMAS
P-ISSN 2615-6849, E-ISSN 2622-3686

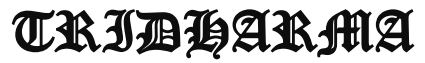
Jurnal ABDIMAS Vol. 2, No. 2, April 2021 Hal (26-38)
AIA
Email: abdimasjurnal.unpam@gmail.com Telp: (021) 741-2566

diskusi dengan tanya jawab. Hasil yang didapatkan warga Desa Belega sangat antusias untuk bertanya terkait bagaimana cara untuk meningkatkan pengembangan karir mereka di masa pandemic Covid-19 saat ini. Untuk peserta yang aktif dan berani bertanya kami berikan reward berupa cinderamata dari Universitas Pamulang dan sumbangsih dari dosen-dosen Universitas Pamulang.

c. $\quad$ Metode Simulasi $\rightarrow$ Penyuluhan ini juga menggunakan metode simulasi, sehingga peserta langsung dapat mempraktekan apa yang sudah disampaikan. Apabila ada kendala yang dirasakan maka langsung dibantu pada saat pelaksanaan PKM. Simulasi ini penting dilakukan untuk mengetahui seberapa besar tingkat pengetahuan dan ilmu yang diserap oleh warga Desa Belega selama penyuluhan.
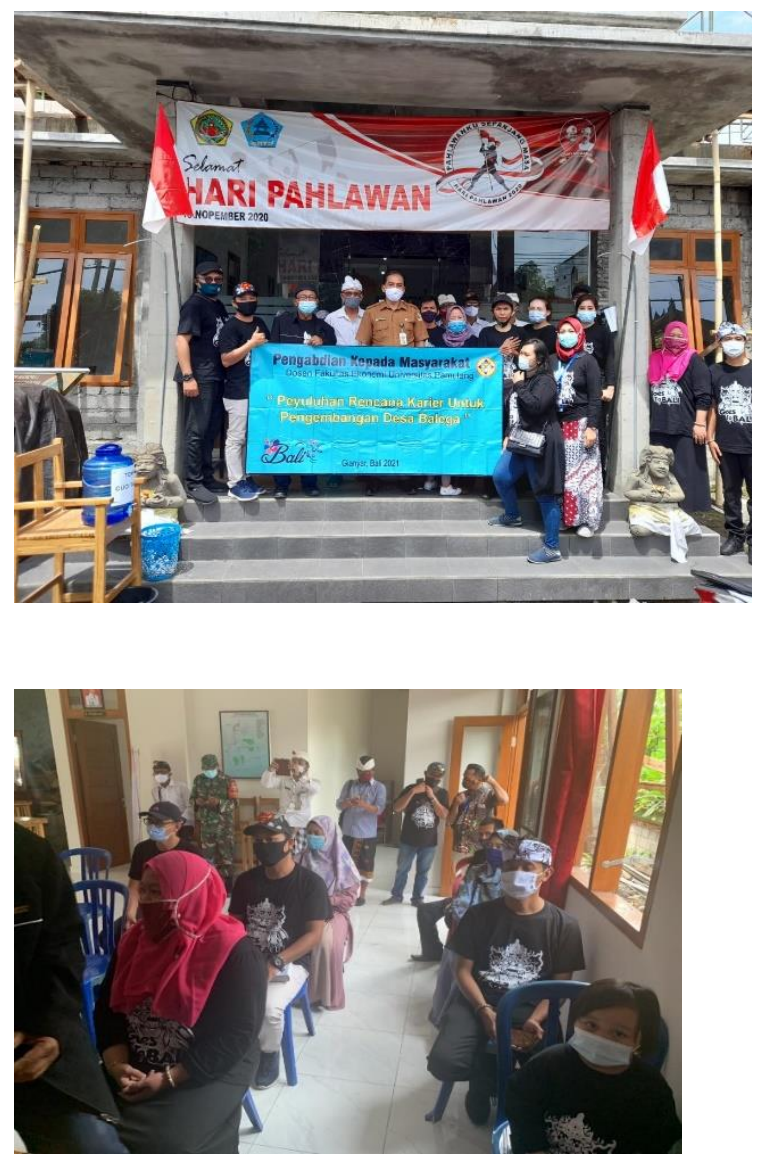
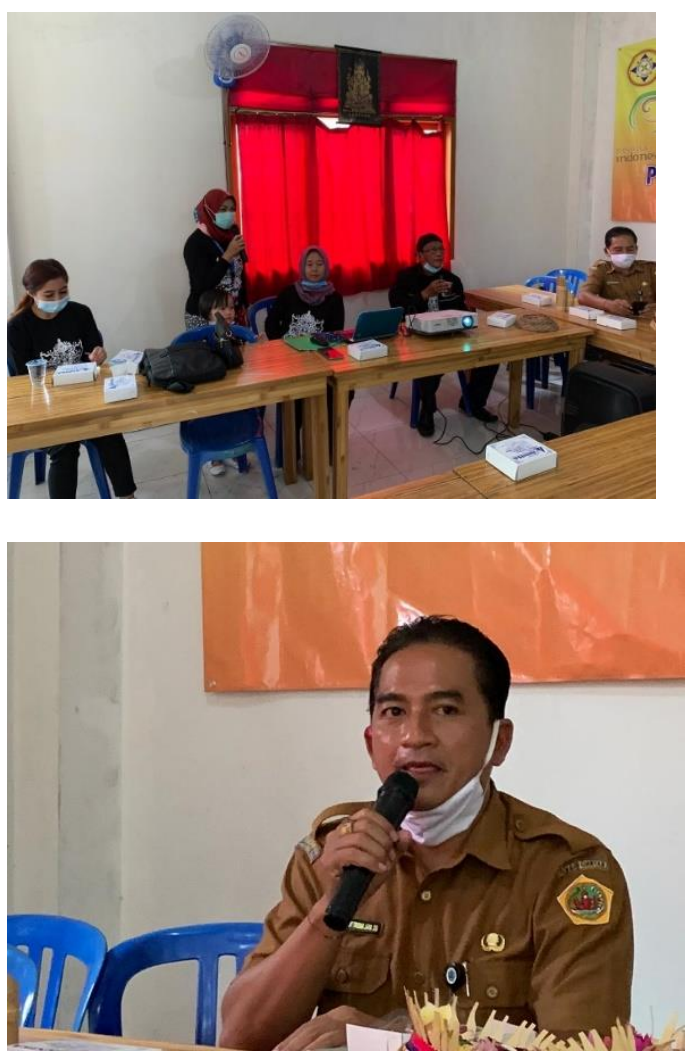

\section{KESIMPULAN DAN SARAN \\ Kesimpulan}

Pelaksanaan

kegiatan

Pengabdian Kepada Masyarakat oleh Lembaga Penelitian dan Pengabdian Masyarakat (LPPM) Universitas Pamulang yang dilakukan oleh dosen-dosen Program Studi Manajemen telah berjalan dengan lancar dan mendapat sambutan positif dan hangat dari tempat pelaksanaan kegiatan PKM di Kelurahan Desa Belega Gianyar Bali. Harapan kami selaku dosen dengan adanya kegiatan PKM ini dapat menambah ilmu yang bermanfaat dalam hal sikap disiplin dan tanggung jawab.

Dalam laporan kegiatan PKM ini mungkin banyak kekurangan yang ada, untuk itu kami berharap masukan dan kritikan dalam rangka perbaikan untuk kegiatan PKM selanjutnya. Semoga kegiatan PKM ini dapat 


\section{JURNAL ABDIMAS

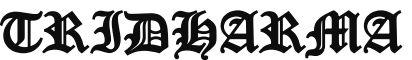

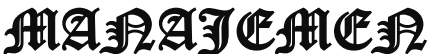

bermanfaat bagi masyarakat di Desa Belega dan Lingkungan Universitas Pamulang pada umumnya.

Akhirnya, kami mengucapkan banyak terimakasih kepada seluruh pihak yang telah mendukung dan berkontribusi dalam kegiatan PKM ini dan kami memohon maaf apabila dalam kegiatan PKM ini banyak ditemukan kekurangan dan kesalahan.

\section{Saran}

Berdasarkan hasil kegiatan PKM yang sudah dilakukan, maka kami dari team Dosen Universitas Pamulang memberikan saran yaitu sebagai berikut :

1. Untuk pihak Kepala Desa dan beserta jajarannya agar lebih menekankan dorongan motivasi kepada warganya untuk meningkatkan perencanaan karirnya serta kompetensinya di masa pandemic Covid-19 saat ini agar waganya menjadi lebih berprestasi kelak di kemudian hari.

2. Adanya kontribusi dari pihak Universitas untuk bisa memberikan fasilitas dalam pelayanan kepada masyarakat dalam bentuk sarana dan prasarana.

\section{DAFTAR PUSTAKA}

1. Dewa Ketut Sukardi, Pengaantar Pengantar Pelaksanaan Program Bimbingan dan Konseling di Sekolah, Rineka Cipta: Jakarta, 2000.

2. Robert L. Gibson \& Marianne H. Pelajar: Yogyakarta, 2011 Bimbingan dan Konseling Pustaka Pelajar Jogjakarta
3. Sutirna, Bimbingan dan Konseling Pendidikan Formal, Nonformal dan Informal, Yogyakarta, 2013

4. Walgito, Bimo, Bimbingan \& Konseling (Studi dan Karir), ANDI OFFSET: Yogyakarta, 2005.

5. Sunarto, A. (2020). Pengembangan Sumber Daya Manusia dengan Berbasis Inovasi Untuk Menghadapi Revolusi Industri 4.0. Jurnal Ilmiah MEA (Manajemen, Ekonomi, \& Akuntansi), 4(2), 397-407.

6. Sunarto, A. (2020). Kinerja Karyawan Berbasis

Kepemimpinan Dan Motivasi Pada PT. Duta Jaya Putra Persada Mining. JENIUS (Jurnal Ilmiah Manajemen Sumber Daya Manusia), 3(3), 246-257.

7. Sunarto, A., Qurbani, D., \& Virby, S. (2020). Pengaruh Kompetensi, Disiplin Kerja Dan Lingkungan Kerja Terhadap Kinerja Pada PT Anugrah Bersama Sejahtera Depok. JIMF (Jurnal Ilmiah Manajemen Forkamma), 4(1).

8. Sunarto, A., Tanjung, A. W., \& Ellesia, N. (2020). Teacher Performance Based on The Visionary Leadership Style of School, Competency and Work Discipline (Study at Muhammadiyah Setiabudi Pamulang College). Journal of Research in Business, Economics, and Education, 2(5), 1046-1052.

9. Ading, S. (2020). PENGARUH GAYA KEPEMIMPINAN, MOTIVASI, SERTA DISIPLIN KERJA TERHADAP KINERJA KARYAWAN (Study di PT Mitsui Leasing Capital Indonesia Abdul Muis-Jakarta Pusat). KREATIF: Jurnal Ilmiah Prodi Manajemen Universitas Pamulang, 8(1), 1838.

10. Sunarto, A., Sartika, D., Cay, S., Sumiyati, R. Y., \& Nurhidayat, M. A. (2020). MENINGKATKAN 


\section{JURNAL ABDIMAS

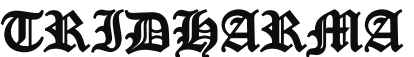

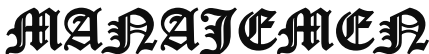

P-ISSN 2615-6849, E-ISSN 2622-3686

Jurnal ABDIMAS Vol. 2, No. 2, April 2021 Hal (26-38)

@ Prodi Manajemen Fakultas Ekonomi Universitas Pamulang

Email: abdimasjurnal.unpam@gmail.com Telp: (021) 741-2566

\author{
MOTIVASI \\ PESERTA DIDIK \\ BELAJAR \\ MASING-MASING \\ DIRUMAH \\ SELAMA \\ MASA PANDEMIC COVID-19 \\ PADA YPMS DARUSSALAM \\ KEDAUNG \\ PAMULANG. DEDIKASI \\ PKM, 2(1), 14-20.
}

11. Apriansyah, M., Agrasadya, A., Sunarto, A., Irawati, L., \& Kencana, P. N. (2020). PENGEMBANGAN SDM RUMAH SAKIT DI TENGAH PANDEMI COVID-19 PADA RS. MEDIKA BSD. DEDIKASI PKM, 2(1), 61-67.

12.Pasaribu, V. L. D., Susanti, F., \& Hartuti, E. T. K. (2019). Memotivasi Siswa dan Siswi SMK Letris Indonesia di Dalam Menentukan Pilihan Untuk Melanjutkan Pendidikan Atau Bekerja Setelah Lulus Sekolah. Jurnal Pengabdian Dharma Laksana, 1(2), 161172.

13.Pasaribu, V. L. D., Agrasadya, A., Shabrina, N., \& Krisnaldy, K. (2020). MENJADI ENTERPRENEUR MUDA YANG
MEMILIKI JIWA LEADERSHIP UNTUK MENGHADAPI MASA DEPAN. Abdi Laksana, 1(1).

14.Pasaribu, V. L. D., Elburdah, R. P., Sudarso, E., \& Fauziah, G. (2020). PENGGUNAAN MANAJEMEN WAKTU TERHADAP PENINGKATAN PRESTASI BELAJAR DI SMP ARAISIYAH. Jurnal ABDIMAS Tri Dharma Manajemen, l(1).

15.Pasaribu, V. L. D., Sulaiman, S., Sutiman, S., Thaharudin, T., \& Purnomo, B. Y. (2020). PENGENALAN LETAK POSYANDU TERDEKAT DIKELURAHAN PISANGAN DENGAN MANAJEMEN PEMASARAN REVOLUSI 4.0 UNTUK MENINGKATKAN PENGETAHUAN MASYARAKAT LETAK DAN FUNGSI POSYANDU TERDEKAT PADA KELURAHAN PISANGAN. DEDIKASI PKM, 1(1), 105-110.

16.Pasaribu, V. L. D., Oktrima, B., Prabowo, B., Arianto, N., \& Haryoko, U. B. (2020). PROGAM PENDAMPINGAN DAN PENYELENGGARAAN PENDIDIKAN ANAK PADA USIA DINI TERHADAP PRESTASI BELAJAR DILINGKUNGAN RT 020 RW 009. KEL GIRI PENI. KEC WATES. YOGYAKARTA. JURNAL LOKABMAS KREATIF, 1(1), 71-75. 